\title{
Despindo a narrativa: uma poética felina (apontamentos acerca da alteridade)
}

\author{
Undressing the narrative: a feline poetics (points about alterity)
}

Desnudando la narrativa: una poética felina (apuntamientos acerca de la alteridad)

\author{
Eliana da Conceição Tolentino*
}

Laís Maria de Oliveira ${ }^{* * * * *}$

\begin{abstract}
Resumo
A partir dos estudos culturais, a interdisciplinaridade das ciências trouxe à tona temas como a questão do ser humano e/ou animal. Nesse espaço denominado animal studies se embrenharam pesquisadores como Jacques Derrida e J. M. Coetzee (escritos sobre o animal), Michael Foucault (loucura e animalidade), Deleuze e Guattari (a noção de devir animal), Peter Singer e Giorgio Agamben (abordagens bioéticas), Eduardo Viveiros de Castro (estudos etnológicos), Maria Ester Maciel (zoopoética), entre outros. Esses estudos se justificam não só pelas preocupações de ordem ecológica, que têm se intensificado atualmente, mas também por certa curiosidade e interesse por parte dos pesquisadores, no que tange à nossa relação com os outros seres e ainda por uma espécie de crise do humano, que tem suscitado muitas discussões entre os pesquisadores. A partir da obra As horas nuas, de Lygia Fagundes Telles, estudamos a construção do lugar fronteiriço entre o humano e o animal no romance e sob a perspectiva teórica dos Estudos animais. Trata-se, assim, de um texto em que procuramos discutir o lugar desse absolutamente outro em nossa sociedade.
\end{abstract}

Palavras-chave: animal, humano, fronteira, alteridade.

\begin{abstract}
With the advent of Cultural Studies, the interdisciplinarity between sciences has raised new questions about the boundaries between mankind and animals. The resulting field of Animal Studies has permeated the works of writers such as Jacques Derrida and J.M. Coetzee (writings about the animal), Michael Foucault (madness and animalism), Deleuze and Guattari (the concept of becoming animal), Peter Singer and Giorgio Agamben (bioethical approaches), Eduardo Viveiros de Castro (ethnological studies), and Maria Ester Maciel (zoopoetics) among others. These studies are justified not only because of growing concerns of ecological order but also because of a certain interest in our relationship to other species, because of a kind of human crisis which has provoked a number of discussions among researchers. In studying the novel As horas nuas by Lygia Fagundes Telles, we try to locate the construction of the boundaries between humans and animals, through a
\end{abstract}

\section{Resumen}

Desde los estudios culturales, la interdisciplinaridad de las ciencias ha traído a la superficie temas como la cuestión del ser humano y/o animal. En ese espacio denominado estudios animales se adentraron investigadores como Jacques Derrida y J.M. Coetzee (escritos sobre el animal), Michel Foucault (locura y animalidad), Deleuze y Guattari (la noción del devenir animal), Peter Singer y Giorgio Agamben (abordajes bioéticos), Eduardo Viveiros de Castro (estudios etnológicos), Maria Ester Maciel (zoopoética), entre otros. Estos estudios se justifican no sólo por las preocupaciones de orden ecológico, que se han intensificado actualmente, sino también por cierta curiosidad e interés por parte de los investigadores en lo que se refiere a nuestra relación con los otros seres y aún por una especie de crisis de lo humano, temas que han suscitado muchas discusiones entre el grupo de expertos. Desde la obra Las horas desnudas, de Lygia Fagundes Telles,

\footnotetext{
* Doutora em letras e professora da Universidade Federal de São João del-Rei (UFSJ), São João del-Rei, MG, Brasil. orcid.org/0000-0001-6464-9640 E-mail: etolentino5@gmail.com

** Doutoranda pela Universidade Federal de Juiz de Fora (UFJF), Juiz de Fora, MG, Brasil. (Dorcid.org/0000-0001-7333-9812. E-mail: lais.oliveira@ifmg.edu.br

${ }^{* * * *}$ Professora do Instituto Federal de Minas Gerais (IFMG), Ouro Preto, MG, Brasil.
} 
theoretical framework of Animal Studies. This article aims to present a discussion about the spaces reserved for those absolutely other in our society.

Keywords: animal, human, frontier, alterity. estudiamos la construcción del lugar fronterizo entre lo humano y lo animal, en la novela y en la teoria acerca de los estudios animales. Se trata, por lo tanto, de un texto en el cual buscamos discutir el lugar de ese outro absoluto en nuestra sociedad.

Palabras clave: animal, humano, frontera, alteridad.

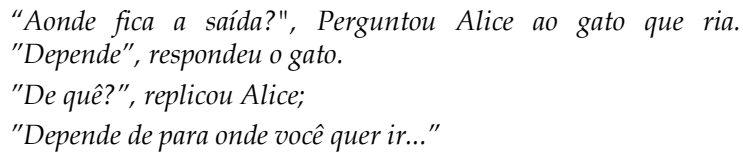

Alice no País das Maravilhas

\section{Marcando o território}

Nos últimos anos, surgiram grupos de estudos sobre os animais, não só na crítica literária, mas também na filosofia, antropologia, ética. A partir dos estudos culturais, a interdisciplinaridade das ciências trouxe à tona temas como a questão do ser humano e/ou animal, ou antes um hibridismo entre ambos. Nesse espaço em que não há separações rígidas, denominado animal studies, se colocam pensadores como Jacques Derrida e J. M. Coetzee (escritos sobre o animal), Michel Foucault (loucura e animalidade), Deleuze e Guattari (a noção de devir animal), Peter Singer e Giorgio Agamben (abordagens bioéticas), Eduardo Viveiros de Castro (estudos etnológicos) e Élisabeth de Fontenay (condição animal), entre outros. Esses estudos se justificam não só pelas preocupações de ordem ecológica, que têm se intensificado atualmente, mas também por uma espécie de curiosidade e interesses aguçados por parte dos pesquisadores, no que tange à nossa relação com os animais e ainda por uma espécie de crise do humano, que tem suscitado muitas discussões.

Jacques Derrida criou a palavra différance que, segundo ele, não é um conceito, mas antes um modo de se pensar o signo e seus significados/significantes. Até pouco tempo, as bases do pensamento ocidental se encontravam na metafísica proposta principalmente por Hegel, em que os signos são definidos a partir da rede de oposições que os distinguem e os relacionam. Assim os conceitos metafísicos eram analisados a partir de seus opositores, tais como corpo/espírito, branco/negro, homem/mulher, cultura/natureza etc. Ao mesmo tempo, a différance serve para ilustrar a crítica do filósofo francês quanto à primazia da oralidade sobre a escrita, uma vez que a troca da letra e (différence) pela letra a (différance) pode ser percebida na escrita e na leitura, mas não pode ser distinguida na fala, já que a pronúncia das palavras é a mesma na língua francesa. Vemos assim que a proposta de Derrida é deslocar esses signos de sua posição binária, sem desprezar o pensamento metafísico:

[...] seja na ordem do discurso falado, seja na ordem do discurso escrito, nenhum elemento pode funcionar como signo sem remeter a um outro elemento, o qual, ele próprio, não está simplesmente presente. Esse encadeamento faz com que cada "elemento" - fonema ou grafema - constitua-se a partir do rastro, que existe nele, dos outros elementos da cadeia ou do sistema. Esse encadeamento, esse tecido, é o texto que não se produz a não ser na transformação de um outro texto. Nada, nem nos elementos nem no sistema está, jamais, em qualquer lugar, simplesmente presente ou simplesmente ausente. Não existe, em toda parte, a não ser diferenças e rastros de rastros (Derrida, 2001, p. 32).

Trata-se, pois, da escrita dos rastros, do limiar, do híbrido entre o signo e suas oposições. Esse pensamento tem derrubado diversas barreiras sobre posições clássicas, fechadas e preconceituosas, principalmente quanto aos estudos de alteridade. Quem é este outro que foi 
muitas vezes renegado pelo pensamento positivista, alvo apenas para o jogo de oposições na definição de conceitos vistos como parâmetros para o pensamento ocidental?

Esse outro é a mulher, o negro, o homossexual, o transexual, o oriental, o estrangeiro e toda a diferença que existe dentro dessas categorias. Aqui, é o animal, que ficou sempre à margem, servindo como signo opositor para celebrar a totalidade do homem, do humano, do ser inteligente. Esse que é alimento, servo, cobaia, dama de companhia do humano. Porém não se trata de utilizar o mesmo método e rebaixar o conceito de humano. O que tentaremos construir é um pensamento do rastro, do espaçamento entre os conceitos, do intervalo, para que os termos signifiquem, funcionem, diferenciem, se aproximem, enfim, dialoguem. Com As horas nuas (1989), de Lygia Fagundes Telles, o pensamento do rastro será relevante na medida em que Rahul transita entre os dois conceitos, quando afirma já ter vivido como humano. Ele é um animal ou estaria animal? Tal qual Gregor Samsa, personagem de A metamorfose (1915), de Franz Kafka, que se transforma em inseto, o gato permeia os dois lugares, está no limiar. Além disso, gato e dona, Rahul e Rosa Ambrósio, parecem se tocar em alguns pontos da narrativa. Seja pela obra, que é atravessada por ambas as vozes de maneira fragmentada, seja pela condição em que ambos se encontram - insatisfeitos com uma existência fadada em um corpo indesejado. Pois se, como afirma Michel Foucault (2010), o corpo é o "lugar irremediável a que estamos condenados", as personagens questionam tal lugar durante todo o romance. Mais que isso, a obra, ao trazer a voz de um animal à narrativa, ao lhe dar uma forma para ser lido, ainda que sob uma perspectiva humana do pensamento animal, abre um espaço necessário para a discussão do animal em nossa cultura e torna-se um convite para olharmos para este outro, que no livro, reflete a própria condição do humano.

\section{Breves apontamentos acerca das obras e da crítica de Lygia Fagundes Telles}

Lygia F. Telles já foi apontada por estudiosos de sua obra, como Carlos Magno Gomes e Suênio Campos de Lucena, como uma escritora que está ciente e comprometida com as questões de seu tempo, uma autora que escreve em plena pós-modernidade. ${ }^{1}$ Assim é comum vermos em suas obras o olhar sobre o outro, ou os outros, em temas como gênero, fazendo uma literatura sobre e em torno do feminino, em contos que refletem sobre a violência contra a mulher, a bissexualidade, o envolvimento político; sexualidade, como em Ciranda de pedra, considerado por ela seu primeiro romance, escrito em 1954, em que vemos a questão da homossexualidade; a loucura e também, a animalidade, que a escritora sempre demarcou, ainda que de forma indireta em alguns textos, como indispensáveis para a reflexão do homem enquanto tal.

Logo em Ciranda de pedra, podemos observar o entrelaçamento do humano ao animal. $\mathrm{Na}$ página que abre o livro, a personagem Virgínia observa uma formiga, identificando-se com ela. Depois de esmagar o inseto, ela reflete sobre o que havia lhe dito Conrado, namorado de sua irmã, e seu amor platônico:

Pensava em Conrado a lhe explicar que os bichos são como gente, têm alma de gente, e que matar um bichinho era o mesmo que matar uma pessoa. "Se você for má e começar a matar só por gosto, na outra vida você será bicho também, mas um desses bichos horríveis, cobra, rato, aranha..." (Telles, 2009, p. 15-16).

Em As horas nuas, temos Rahul, o gato, a rememorar suas vidas passadas como humano. Lygia F. Telles já afirmou, em várias entrevistas, a reaparição de personagens em outros romances, sob uma outra máscara. Segundo a escritora, seus personagens gostam muito de viver, e teimam em voltar à cena. Como esclarece Silviano Santiago, no posfácio de Ciranda de pedra, a formiga é o duplo de Virgínia, diferente dela porque não pressente a morte. Ao se abrir à experiência do

\footnotetext{
${ }^{1}$ Os professores apontaram o engajamento político da escritora em mesas redondas e em minicurso oferecidos durante o V colóquio Mulheres em Letras, na UFMG, que ocorreu durante os dias 18, 19 e 20 de abril de 2013. Minicurso: Leituras da violência nos contos de Lygia Fagundes Telles e mesa redonda As faces da escritora no romance de Lygia Fagundes Telles - Carlos Magno Gomes (UFSE); Mesa redonda Representações da memória e da família em Lygia Fagundes Telles - Suênio Campos de Lucena (UNEB).
} 
inseto, Virgínia afirma sua personalidade desnorteada, ainda em formação. "O amálgama estilístico criado por Lygia vai superar, no entanto, a separação e o distanciamento entre o mundo humano e o animal, enlaçando-os" (Santiago, 2009, p. 207) ou ainda "Compete à Virgínia renegar o medo e o ódio inculcados pela estranha ciranda, fazendo-os submergir na alucinação e no delírio, nos quais o humano e o animal comungam o mesmo cotidiano" (Santiago, 2009, p. 207).

No posfácio de Antes do baile verde, Antonio Dimas compara Lygia F. Telles a uma gata, já no título de seu texto, "Garras de veludo". Para Dimas, a grande dama da literatura aproxima-se do leitor como seus gatos, de que ela tanto gosta. E mais adiante, um conselho do crítico a nós, leitores:

Não se engane com essa sinuosidade felina, felpuda. [...] Porque, quando você menos espera, as unhas retráteis aparecem e, logo depois delas, o risco na carne, o filetinho de sangue escorrendo. [...] Fique esperto! Não confie no ron-ron de Lygia Fagundes Telles (Dimas, 2009, p. 182).

Aqui temos não só a obra, mas a própria escritora sendo comparada a um animal, o que evidencia seu olhar sobre o humano-animal. Ora, em As horas nuas, além da ausência de uma narrativa linear, num emaranhado de vozes que se entrecruzam, não há um desfecho no livro. Sabemos que a protagonista, Rosa, se interna numa clínica de reabilitação, mas não sabemos o momento em que isso ocorre; a personagem Ananta desaparece no meio do romance, sem deixar rastros e temos a chegada de um novo personagem, nunca mencionado até então, Renato Medrado, primo de Ananta, que surge para tentar desvendar o mistério do sumiço da prima, que também não é revelado no livro. O único que se mantém firme até as páginas finais do livro é Rahul, observando tudo e todos através dos seus olhos de gato.

\section{"Sair da vida ao nível do chão" - a relação entre humano e animal}

É bom ter um monte de gatos em volta. Se você está mal, basta olhar para eles e fica melhor, porque eles sabem que as coisas são como são.

Charles Bukowski

De nossa primeira leitura de As horas nuas, ficou na memória a estranha sensação de, depois de ter lido o primeiro capítulo e ter nossos primeiros contatos com Rosa Ambrósio (a personagem decadente e alcoolista), ler o segundo capítulo e descobrir que aquele narrador, relembrando sua vida de jovem poeta no Império Romano, era um gato. Um gato com memórias? Estranhamos; mais tarde o próprio Rahul iria se questionar sobre isso. Não bastasse um narrador felino, havia o agravante das memórias: tratavam-se de memórias de uma vida como humano, numa descrição poética da primeira experiência sexual do narrador:

Beija esse ombro, me toma pela cintura e colado ao meu corpo ele vai me levando adiante feito um escudo. Tombo de joelhos no leito, os cotovelos fincados no coxim. Agora ele me agarra pelos cabelos e puxa minha cabeça. Vou cedendo, o pescoço distendido em arco. Ainda não posso vê-lo colado assim às minhas costas nem me esquivar quando sua boca voraz mordeu minha nuca, devo ter gemido porque em seguida a boca procurou suavemente minha orelha, contornou a orelha com a língua. [...] Minhas pernas vão vergando submissas, escorregadias. Deixei cair a túnica e agora estamos nus e calmos, o suor escorrendo e se misturando. É a primeira vez, eu quis dizer para justificar a minha inexperiência. Não consegui falar, inundado de um gozo tão profundo que em meio do tumulto fui tomado por um sentimento de paz (Telles, 1989, p. 24).

A descrição de uma cena interessante - dois rapazes fazendo amor - que aos poucos vai se dissolvendo, ficando vaga e, então, a surpresa de uma voz animal na narrativa.

Digo adeus à casa romana com o visitante que nem cheguei a encarar, guardei seu cheiro. E a fugidia visão do seu corpo antes de se perder no meu, bem viva a imagem do jovem do baixo-relevo subjugando o touro. Com o reflexo móvel da minha boca no vinho roxo que esvaziei. Apertei meu peito inquieto com a palma da mão como faço agora. A diferença é 
que já não tenho uma mão à altura do gesto, mas uma pata. Veludosa. As unhas bem aparadas para não puxar o fio dos tapetes de Rosa Ambrósio (Telles, 1989, p. 25).

Sim, este narrador é um bicho de estimação de Rosa Ambrósio, que passa o tempo a rememorar suas vidas passadas e a observar a dona, cada vez mais entregue à bebida. No entanto, como animal, não pode falar como os humanos, tem de contentar-se em observar - todos e tudo a sua volta. O passado o impele a falar, foi tão bonito, é preciso o relato, nem que seja para que a memória de tudo não morra. Então ele se direciona ao leitor, quer abrir-se, mostrar-se nu, tal qual sua dona. O fluxo de consciência proporciona esse prazer, ele conta e reconta seus mistérios, os seus medos. Quer abrir a porta, já não pode, é um felino e resigna-se a viver com seus donos, num mundo cercado por rodapés. Há o desejo de verticalizar-se, mas é sonho, voltará a viver como humano um dia? Nesse gato, os vícios humanos, tão impregnados no pensamento, convivem com o apetite de bicho, marcando sua dupla condição: corpo de animal e alma humana.

Derrida (2002) bem lembra da crise do humano diante do animal: quem é esse que me olha? Quem sou eu? Mas e aqui, e esse personagem, que esteve na condição humana e agora retorna como animal, e como gato, ser tão simbólico na literatura? Viver duas condições tão diferentes, e agora se perder na reflexão sobre ambas.

E se eu tivesse que morrer para nessa segunda oportunidade me aproximar dele (Gregório) novamente? Se é que a gente pudesse se reencontrar - eu disse a gente? Eu disse a gente. Porque a ideia de ser de novo um bicho é tão dilacerante que continuo a me perguntar, no mesmo tom culposo de Rosona, o que eu fiz, o quê?! Para merecer esta forma. E não tenho fé, não acredito em nada. Um gato moralista e agnóstico - existe? Memória que quase sempre é peçonha na qual me alimento. E me enveneno. Recuei. Saltei para o tapete. Agora tenho medo da liberdade (Telles, 1989, p. 115).

Rahul então vive, felino e fadado à memória de suas vidas humanas. Memória que é veneno, porque dói e dilacera, mas também remédio para distração e procura de uma identidade. Phármakon tal qual precipitou Platão. Rahul configura-se então como espelho, espelho de Rosa, espelho da narrativa em geral. $\mathrm{O}$ único que viu o suicídio de Gregório, ex-militante contra a ditadura militar e marido de Rosa. Rahul, seu devoto. Ele confessará, em determinado ponto do romance, que Gregório é sua alma gêmea, era ele o seu amante na vida de poeta que levou na Roma Antiga. É ele quem nos encena seu cotidiano, porque ela só pensa no seu uísque e no seu passado glorioso. E o questionamento de Montaigne, citado por Derrida, tão presente: "Quando eu brinco com minha gata, quem é que sabe se ela passa seu tempo comigo mais do que eu o faço com ela?" (Derrida, 2002, p. 20). Nessa obra, é Rahul quem se distrai com Rosa e com os demais personagens, porque sua vida de gato é pacata: dormir na poltrona, comer ração, urinar nos sapatos de Diogo, vomitar bolas de pelo nos tapetes de Rosa, porque ele é um gato genioso.

Um animal genioso? Aqui talvez se inicie nosso questionamento. Como pensar, nas palavras de Derrida (2002, p. 29), esse "completamente outro que eles chamam animal, e, por exemplo, um gato"? Sigamos o modus operandi de Eduardo Viveiros de Castro (2008), tentando fazer uma "descolonização do pensamento", deixando por um instante nosso olhar ocidental e eurocêntrico fora disso. Tarefa que nos parece impossível, em se tratando de se pensar como animal. Afinal, quando Viveiros de Castro propõe esse tipo de olhar etnográfico, ele ainda está lidando com o humano. E esse outro, esse que sempre esteve presente na vida humana, na cadeia alimentar, no trabalho diário, mas que ainda nos parece tão misterioso, tão inalcançável?

Foi durante um fato banal, cotidiano, que Derrida (2002) lançou seu olhar reflexivo para o animal, quando começou a se debruçar sobre esse absoluto outro, ainda que filósofos como Platão, Aristóteles, Hegel, Descartes e Kant já tenham tocado na questão. Para tais pensadores, no entanto, o animal seria apenas um autômato biológico, numa oposição ao que define o humano enquanto ser racional, ocasionando uma separação rígida entre os seres. Também Freud (1990a), no início do século XX, começa a indagar sobre um fundo de animalidade a que ele chamou instinto, e do qual postulou uma teoria da repressão sobre nossa vida humana e, mais especificamente, sobre a sexualidade. 
O fato banal em torno de Derrida (2002) que havíamos mencionado se trata de um caso autobiográfico: um dia, ao sair nu do banheiro, após o banho, o filósofo foi surpreendido visto por sua gata, num olhar penetrante e inquisidor. Envergonhado, Derrida se cobre, e percebe em seu ato mais um traço de nossa humanidade - a consciência da nudez - enquanto aquele outro em sua frente, aquele que o olha sem nenhum pudor, encontra-se nu, completamente à vontade em sua pelugem. Ora, está armada a cena para todo um novo tipo de pensamento: Quem é este que nos olha, tão à vontade em sua nudez, e que nos deixa envergonhados, por tratar-se de um ser vivo, com olhos penetrantes?

Dizer dessa alteridade não é fácil, pois, por mais que tentemos nos afastar de nossa pele humana para adentrar essa pele que nos convida a habitá-la, há a cultura e uma herança humana da experiência. No entanto, existe a arte. Seja através do cinema, como sugere Deleuze e Guattari (2012) ao relembrarem o devir animal que atravessa o filme Willard (1972) de Daniel Mann, seja através da literatura, como propõe Derrida.

É nesse sentido que escritores como J. M. Coetzee e Maria Esther Maciel encontram também na poesia uma maneira de pensar a animalidade. Em A vida dos animais, de Coetzee, quando a personagem Elizabete Costello cita o poema "Jaguar", de Ted Hughes, ela fala sobre como o poema nos pede para nos imaginarmos no jeito de se mover do jaguar, num convite a habitar aquele corpo. Na reflexão sobre um dos poemas do escritor Herberto Hélder, Maria Esther Maciel (2011) fala de um saber do outro, no caso, o de uma serpente, que se manifesta pelos sentidos do poema, numa constatação da outridade radical, bem como da afinidade intrínseca que une a serpente ao eu poético.

Voltemos a Rahul. A personagem felina de As horas nuas - que carrega já no meio do nome o $\mathrm{H}$ de humano - foi castrado por sua dona. Estaria esse fato ligado à memória de sua homossexualidade na Roma Antiga? Talvez. Talvez nem haja memórias, quem sabe são sonhos que a personagem tem e que quer transformar em realidade. Desejo de tornar-se humano. Mas para Deleuze e Guattari (2012), um animal de estimação já é humanizado desde que seja adotado e more com humanos. Gatos e cães, para os pensadores, já perderam sua animalidade natural desde que entraram em contato com o humano, numa relação doméstica, familiar. A animalidade, para eles, está mais ligada ao selvagem, à ideia de bando, de grupo, de coletividade, do incontrolável. Mas há que se lembrar, e Derrida (2002) bem o faz, que mesmo os animais selvagens foram nomeados pelo homem, tanto na criação do mundo, como podemos observar na Bíblia, especificamente no "Gênesis", quanto na ciência, no estudo das espécies. Até mesmo a nós coube dizer o que é o selvagem e o que não o é. E disso ainda desponta a velha questão filosófica: quem nasceu primeiro, o homem ou o animal? $\mathrm{O}$ ovo ou a galinha? O livro sagrado nos diz que os animais, ainda que criados antes do homem, só passaram a existir enquanto palavra depois do homem, que os chamou por seus nomes. E segundo a evolução das espécies, o homem, como o configuramos hoje, surge quando convoca os primeiros fonemas, as primeiras pinturas - tentativas de se narrar? Mais uma vez a linguagem. Todos os seres vivos têm sua própria linguagem, ainda que sob fonemas e signos distintos. Talvez o grande único diferenciador do homem enquanto espécie privilegiada seja a invenção do código escrito, da grafia, da pintura, do símbolo impresso em paredes, papéis e no próprio corpo.

\section{Da animalidade presente no humano}

Se podemos capturar os animais, torná-los posse, mercadoria, objeto, não podemos capturar seu pensamento ou o sentido do que é ser animal. Mas tentemos, ao menos, conceber a animalidade como ela se apresenta a nós - via instinto. Ainda que "espécie evoluída", somos atravessados pela natureza, pela zoé, que, como explica Giorgio Agamben (2002), exprime o simples fato de viver comum a todos os seres vivos. Enquanto seres viventes, tanto animal quanto humano seguem etapas: ambos nascem, crescem, se reproduzem e morrem. Dentro dessa lógica, há muitas outras semelhanças: o desenvolvimento de habilidades motoras para a sobrevivência, a relação com os outros, que podemos chamar de bando, tribo ou sociedade, a escolha do parceiro sexual para a reprodução. 
O primeiro impulso para tentar escapar à animalidade veio de nossa vontade de sair da realidade: os sonhos assim revelam. Mas não se trata apenas do sonho entendido literalmente, pois disso os animais compartilham - já foi mais do que provado que animais também sonham enquanto dormem. Trata-se do sonho enquanto coisa inalcançável. É o que nos lembra Guimarães Rosa no grande sertão da literatura: que o animal-homem carrega consigo a vontade do depois, daquilo que ele ainda não tem, o desejo de seguir algo que não pertence naturalmente a ele. Talvez tenha sido esse o motivo do grande despertar do animal humano. Querer ser algo mais, ter ciúme de outros bichos que podiam voar ou trocar de pele, por exemplo. Daí a criação da ferramenta, que passou de utensílio de sobrevivência a objeto de luxo. Máquinas de fazer o homem voar, atravessar rios, construindo pontes e navios. Mas a outra ponte, a que ele deixou, essa não se destruiu. Ficou o fundo daquilo que um dia fomos. É essa ponte que Rahul, esse felino literário, tenta nos revelar:

Fugi da interpretação e fui espairecer na saleta onde Diogo esqueceu o televisor ligado. Um cômico macaqueava um macaco sem a graça do macaco. Quando Rosona retornou à sala, eu dormia-acordado na minha almofada. Alisou o pelo do meu pescoço e disse que por falar em água, ia me dar um banho, eu estava com cheiro de jaula. Olhei-a nos olhos. Deslavada mentira, mas deixei-me levar. E se apanhasse uma pneumonia? Se morresse? Na rota convencional das fitas fantásticas, toda fera maldita vira gente na morte. Assim que o policial se aproxima, a pantera ou lobo já é um homem estendido na calçada em meio da poça de sangue. Podia ser que na morte eu voltasse à casa romana, certamente corriam outras águas no rio onde nadei, mas eu seria o mesmo. Aceitando com naturalidade os prodígios até chegar à minha casa no ocaso de vermelhidão e vinho. Reconhecendo dessa vez o amante que veio por detrás e tocou meu ombro, Gregório (Telles, 1989, p. 29).

O sentimento de pertença ao humano faz de Rahul um prisioneiro de suas memórias, ainda que elas possam ser inventadas. Condenado a uma vida vertical, os pensamentos desse animalhumano sequer chegam aos outros, apenas a nós, leitores do romance. Para os demais personagens com quem convive, ele é apenas um bichano castrado e folgado. Uma distração para a dona, que não faz outra coisa que se lamentar da vida e beber compulsoriamente. Diferente de Gregor Samsa, que só passa a ser realmente notado e existir para os outros quando se transforma em inseto, Rahul é anulado por sua condição animal. A vida para ele se torna um eterno retorno a suas memórias de humano. Mas por que essa fixação pela humanidade?

A utopia do humano. Mais uma vez o sonho, a vontade de ser mais do que se é ou está. No entanto, quando pensamos na finalidade da vida em geral, zoé, ficamos um tanto quanto sem resposta. Freud diria que a pulsão de vida e as ocupações do homem, como o trabalho e o lazer, foram criados para evitar a autodestruição humana. Em O mal-estar na civilização, afirma:

A questão do propósito da vida humana já foi levantada várias vezes; nunca, porém, recebeu resposta satisfatória e talvez não a admita. Alguns daqueles que a formularam acrescentaram que, se fosse demonstrado que a vida não tem propósito, esta perderia todo o valor para eles. Tal ameaça, porém, não altera nada. Pelo contrário, faz parecer que temos o direito de descartar a questão, já que ela parece derivar da presunção humana, da qual muitas outras manifestações já nos são familiares. Ninguém fala sobre o propósito da vida dos animais, a menos, talvez, que se imagine que ele resida no fato de os animais se acharem a serviço do homem. Contudo, tampouco essa opinião é sustentável, de uma vez que existem muitos animais de que o homem nada pode se aproveitar, exceto descrevê-los, classificá-los e estudá-los [...] (Freud, 1990b, p. 83, grifo do autor).

O que separa efetivamente o homem do animal é o fato de que este não faz elaborações cerebrais tão complexas como, por exemplo, se questionar sobre a razão de estar no mundo, pelo menos é o que se tem enquanto dado. Essa reflexão, que faz do homem espécie privilegiada, é também motivo para uma de suas maiores angústias. O humano em nós não se contenta com "a vida como ela é", buscando sempre algo que nos tire da realidade. Para isso, mais uma vez, a invenção da arte. Segundo Antoine Compagnon (2001, p. 15): “Assim, a literatura, ao mesmo tempo sintoma e solução do mal-estar na civilização, dota o homem moderno de uma visão que o leva além das restrições da vida cotidiana". 
Como pensar a relação animal com o mundo? Seria exclusividade do humano sair da objetividade, da vida puramente biológica? O que a filosofia contemporânea tenta fazer hoje quanto à questão do limite entre humano e animal é justamente derrubar essa fronteira. Derrida nos diz de como a filosofia tradicional construía seus argumentos com base na ideia de tese, rebatida por uma antítese, que terminaria numa síntese. As ideias eram embasadas pela dicotomia entre conceitos, por uma lacuna entre os termos. Assim o humano era definido a partir das suas diferenças com o animal. No entanto, com o pensamento de pós-estruturalistas como Deleuze, Foucault e do próprio Derrida, a filosofia passa a se preocupar justamente com essas fissuras entre os termos. O que Derrida chama de pensamento do rastro é a constatação de que mesmo entre pares opositores de conceitos nunca há um corte de pensamento dos termos, eles estão sempre ligados, não havendo uma separação.

Para nós, oriundos de uma cultura ocidentalizada, marcada pela hierarquia do humano sobre o animal, é difícil imaginar esse outro em uma relação próxima conosco. A proximidade estaria apenas no fundo ou na herança animal que carregamos. No entanto, o antropólogo Viveiros de Castro, ao pesquisar ameríndios da Amazônia, descobriu uma forma completamente diferente de pensamento: para eles, o fundo comum entre nossa espécie e as outras é a humanidade. Cada espécie se sente humana diante das outras: a onça se vê como gente e vê a nós, humanos, como porcos selvagens, por exemplo, e por isso nos caça e come. Os porcos selvagens, por sua vez, se pensam humanos, enquanto nós somos vistos por eles como espíritos canibais, pois os caçamos e os comemos. Para os ameríndios, todas as espécies reivindicam a humanidade para si, ou seja, se pensam humanas diante de outros seres.

Pensar o sujeito hoje é cogitar sobre a vida em geral, é a possibilidade de todo ser vivente tornar-se sujeito. Mais que isso, é a chance de seres humanos até então assujeitados tornarem-se sujeitos. Por isso a mudança de vocabulário, a criação de conceitos ligados à natureza, à zoé, tais como desterritorialização, rizoma, fronteira, raiz, devir-animal, influenciados principalmente por Deleuze e Guattari. Deleuze e Parnet (1998, p. 74) vão além na definição dos seres: "Você ainda não definiu um animal enquanto não tiver feito a lista de seus afetos".

Derrida, em $O$ animal que logo sou, cria um novo vocábulo para pensar filosoficamente o animal, que ele nomeia animot. Tal expressão seria a junção das palavras francesas animaux (animal) e mot (palavra), ou seja, o animal enquanto discussão, e ainda enquanto escritura, que se configura com sua inserção no pensamento filosófico tendo em vista a criação de um conceito próprio para o tema. Em As horas nuas, temos um felino que pensa como humano e que existe enquanto ser de papel, enquanto literatura, escritura, personagem. E que, tal como a gata do filósofo argelino/francês, observa sua dona no banho, no espelho, em seu cotidiano: "Não sei por que fez isso na minha frente, isso que fez, tingir os pelos. ${ }^{2}[\ldots] \mathrm{O}$ despudor das pessoas diante dos bichos, mas sou um bicho? Um bicho" (Telles, 1989, p. 93). Ademais, questiona seu próprio pensamento de animal-humano - seria tudo invenção?

[...] não havia dois caleidoscópios mas apenas um, inventei o outro. Como inventei esta alma transmissível e transmigrante, vírus que habitou três corpos até chegar a este atual. Não houve nenhum colar de prata com a inscrição, não houve nada disso, o que estava no pescoço do jovem romano seria apenas a coleira que Rosona resolveu afivelar no meu pescoço e que acabei estraçalhando nos dentes, não era isso? Foi para fugir de mim mesmo que inventei os outros corpos, que me alimentei desses outros, tão simples tudo. Tão simples, concluí e me deitei sem forças. Diogo deixou o caleidoscópio e ligou o toca-discos, Que gato mais triste! Um pouco de jazz vai te animar, garoto. Ligou o toca-discos e logo se esqueceu de mim, ouvindo em êxtase o saxofone (Telles, 1989, p. 53).

Rahul estabelece entrecruzamentos entre a humanidade e a animalidade. É aquele que está animal, mas se pensa enquanto humano. O mesmo acontece com Gregor Samsa, em A Metamorfose: ao se transformar em inseto, a personagem não perde seu pensamento humano, nem seu status

\footnotetext{
${ }^{2}$ Optamos por atualizar as palavras das citações de acordo com a nova ortografia.
} 
social de homem, já que continua a viver com a família, a trabalhar no escritório, até seu final trágico, pois não consegue mais conviver com sua situação ambígua, pertencente aos dois mundos.

No Abecedário de Deleuze, quando o filósofo é questionado sobre o vocábulo animaux, ele argumenta:

E, quem sabe, poderia haver um escritor que conseguisse. O piar doloroso, todos dizem, bem, sim, Kafka. Kafka é A metamorfose, o gerente que grita: “Ouviram, parece um animal”. Piar doloroso de Gregor ou o povo dos camundongos, Kafka escreveu pelo povo dos camundongos, pelo povo dos ratos que morrem. Não são os homens que sabem morrer, são os bichos, e os homens, quando morrem, morrem como bichos. Aí voltamos ao gato e, com muito respeito, tive, entre os vários gatos que se sucederam aqui, um gatinho que morreu logo, ou seja, vi o que muita gente também viu, como um bicho procura um canto para morrer. Há um território para a morte também, há uma procura do território da morte, onde se pode morrer. E esse gatinho que tentava se enfiar em um canto, como se para ele fosse o lugar certo para morrer. Nesse sentido, se o escritor é alguém que força a linguagem até um limite, limite que separa a linguagem da animalidade, do grito, do canto, deve-se então dizer que o escritor é responsável pelos animais que morrem, e ser responsável pelos animais que morrem, responder por eles... escrever não para eles, não vou escrever para meu gato, meu cachorro. Mas escrever no lugar dos animais que morrem é levar a linguagem a esse limite. Não há literatura que não leve a linguagem a esse limite que separa o homem do animal. Deve-se estar nesse limite (Boutang, 1996). ${ }^{3}$

Se a literatura leva a linguagem ao limite que separa o homem do animal, Lygia Fagundes Telles fez jus a esse estatuto em seus livros, que trazem a relação entre humanos e animais. No conto "História de passarinho", publicado em Antes do baile verde, o homem do cabelo ruivo, morador tradicional de um bairro em São Paulo, encontra um filhote de pássaro (que ele tem dúvidas se é um canário ou um pintassilgo) caído de algum ninho e faz dele seu bicho de estimação. À medida que o tempo corre, homem e ave irão compartilhar o mesmo desejo: a vontade de fugir da prisão - da gaiola ou de uma vida comum. Um dia, o filho, irritado com o seu canto, o solta da gaiola, e um gato o come, deixando como prova do crime uma única pena do bicho. $\mathrm{O}$ homem decide-se: guarda a pena no bolso, abre o portão e vai embora. $\mathrm{O}$ homem era o pássaro, que finalmente se liberta da gaiola, daí quem sabe a ruivez do cabelo seja indício de sua relação com o animal de estimação. Assim também em Ciranda de pedra, quando Virgínia entra em um co-habitar com a formiga que ela esmaga, como se esmagasse sua própria vida.

Os animais, nas obras de Lygia F. Telles, se tornam metáfora ou mote para uma discussão sobre a humanidade ou sobre a vida. Se, como nos lembra Deleuze, o animal procura um território para morrer, se ele está sempre à espreita, o escritor talvez esteja mais próximo dos animais do que outros homens, pois também o escritor está sempre à espreita de algo, e também ele procura o seu próprio território, em sua escritura. Kafka renunciou ao casamento, a uma vida comum, para se dedicar à sua obra porque acreditava que, se tivesse uma vida como a de todos, não conseguiria se dedicar à literatura. Kafka escolheu seu território, procedendo como o animal.

Deleuze fala ainda em relações animais com os animais, que seriam o verdadeiro ponto de contato entre nós e eles, e não através de relações humanas com os animais, como costumam ser aquelas entre dono e bicho de estimação. Para ele, o caçador, ainda que numa relação de conflito com a criatura caçada, estabelece uma relação animal ao travar com esta uma comunicação selvagem, de instinto de caça.

Para algumas culturas indígenas, no entanto, a relação com os bichos não é uma relação animal, mas sim humana, já que para eles o fundo comum entre todos os seres vivos é a humanidade.

Nessa perspectiva, parte-se do pressuposto de que somos todos espíritos de uma mesma origem, destinados a viver em corpos distintos. A relação simbiótica com os animais nessas tribos é muito mais íntima do que a das sociedades ocidentais. É comum a imagem de índias

\footnotetext{
${ }^{3}$ O Abecedário de Gilles Deleuze (entrevista) é uma realização de Pierre-André Boutang, produzido pelas Éditions Montparnasse, Paris. No Brasil, foi divulgado pela TV Escola, Ministério da Educação. Tradução e Legendas: Raccord [com modificações]. Disponível em: http://escolanomade.org/images/stories/biblioteca/downloads/deleuze-o-abecedario.pdf. Acesso em: 5 de ago. 2013.
} 
amamentando seus bebês em um seio, enquanto no outro mama um filhote de bicho. Aqui percebemos como a cultura é fundamental no processo de concepção e convivência com os animais. Isso não significa que o animal fique fora da cadeia alimentar das tribos. Mas a maneira de encarar a morte deste é muito distinta. Em tribos antropofágicas, assim como comer o corpo do inimigo é um ritual de respeito ao morto, em que suas qualidades positivas (coragem, força etc.) são passadas para os outros através de sua carne, assim também o corpo do animal abatido é considerado. Em rituais xamânicos, a pele do animal serve como instrumento simbólico para que o cacique possa adentrar-lhe o corpo, podendo assim se transmutar em onça ou outro bicho, para intuir perigos como presenças estranhas no território, a previsão do tempo etc. O chefe da tribo é de tal modo, durante determinados rituais, transpassado pelo devir-animal.

E quanto a Rahul, esse nosso gato ficcional, castrado e frustrado com sua vida? Esse, sim, reflete sobre sua existência animal. Mesmo que suas vidas passadas sejam inventadas para preencher o seu tempo, tem um espírito inquieto e criativo. Ele sabe que além de estar como animal, subjugado pelo homem, encontra-se como felino, espécie que compete com o humano pela liberdade e destreza que inspira.

A angústia de saber-se corpo animal com um pensamento controverso. Um pensamento que não se contenta em apenas dormir, caminhar, comer e brincar com um novelo de lã, um pensamento que se percebe humano, na medida em que sente falta de um passado, que sonha com algo mais, que não se contenta em ser como se é, apenas. A dor de se saber existência. Dor. Ponto em que todo ser vivente se encontra, lugar em que as fronteiras são apagadas, enquanto aspecto físico, o sofrimento. Como reitera Derrida (2002, p. 56): “Ninguém pode negar o sofrimento, o medo ou o pânico, o terror ou o pavor que podem se apossar de certos animais e que nós, homens, podemos testemunhar". De fato, homem e animal agonizam da mesma forma na hora da morte. Aqui talvez caiba pensar a ética, ou a falta desta, na potência avassaladora em que se tornou a cadeia alimentar humana. Criadas especificamente para serem comidas pelos homens, certas espécies são consideradas meros objetos, coisificadas pela indústria alimentícia, que produz animais em escalas cada vez maiores. Ainda que estranho, o termo é ideal: produção de animais. Como pontua Georges Bataille:

$\mathrm{O}$ animal perdeu a dignidade de semelhante ao homem, e o homem, ao perceber em si mesmo a animalidade, a vê como uma tara. Há, sem dúvida, um pouco de ilusão no fato de olhar o animal como uma coisa. Um animal existe para si mesmo, e para ser uma coisa deve ser morto ou domesticado. Assim, o animal comido só pode ser tomado como objeto se for comido morto. Na verdade, ele só é plenamente coisa sob a forma de assado, de grelhado, de guisado. [...] Quando mato, corto, cozinho, afirmo implicitamente que aquilo nunca foi nada além de uma coisa (Bataille, 1993, p. 35, grifo do autor).

Para afirmar sua humanidade e garantir o topo da hierarquia das espécies, o homem transforma o animal em coisa. Manipulado geneticamente, o animal tem a vida controlada antes mesmo de seu nascimento, e destinada a um único objetivo: a alimentação humana. Vivendo em gaiolas apertadas, sem luz e sem espaço para se movimentar, os animais manipulados pela produção de carne têm uma existência fadada a comer: comer o tempo todo alimentos cheios de hormônios para que cresçam e engordem o mais rápido possível, para então serem abatidos e levados para os supermercados, onde o consumidor tem o simples trabalho de desembrulhar a bandeja, temperar seus corpos e degustá-los, numa bela ceia.

\section{Referências}

AGAMBEN, Giorgio (2002). Homo Sacer: o poder soberano e a vida nua I. Tradução de Henrique Burigo. Belo Horizonte: Editora UFMG.

BATAILLE, Georges (1993). Teoria da religião. Tradução de Sergio Goes de Paula e Viviane de Lamare. São Paulo: Ática. 
CASTRO, Eduardo Viveiros de (2008). Eduardo Viveiro de Castro. Coleção Encontros. Rio de Janeiro: Bico do Azougue.

COETZEE, J. M. (2002). A vida dos animais. Tradução de José Rubens Siqueira. São Paulo: Companhia das Letras.

COMPAGNON, Antoine (2001). O demônio da teoria: literatura e senso comum. Tradução de Cleonice Paes Barreto Mourão e Consuelo Fortes Santiago. Belo Horizonte: Editora da UFMG.

DELEUZE, Gilles; GUATTARI, Félix (2012). Mil platôs: capitalismo e esquizofrenia, v. 4. 2. ed. Tradução de Suely Rolnik. São Paulo: Ed. 34.

DELEUZE, Gilles; PARNET, Claire (1998). Diálogos. Tradução de Eloisa Araújo Ribeiro. São Paulo: Escuta.

DERRIDA, Jacques (2001). Posições/Jacques Derrida. Tradução de Tomaz Tadeu da Silva. Belo Horizonte: Autêntica.

DERRIDA, Jacques (2002). O animal que logo sou. Tradução de Fábio Landa. São Paulo: Unesp.

DIMAS, Antonio (2009). Garras de veludo. In: TELLES, Lygia Fagundes. Antes do baile verde. São Paulo: Companhia das Letras, p. 181-196.

FOUCAULT, Michel (2010a). História da loucura. Tradução de José Teixeira Coelho Neto. São Paulo: Perspectiva. FOUCAULT, Michel (2010b). O corpo utópico. Página/12, Buenos Aires, p. 10, 29 out.

FREUD, Sigmund (1990a). Totem e tabu. In: FREUD, Sigmund. Edição standard brasileira das obras psicológicas completas de Sigmund Freud. Rio de Janeiro: Imago. v. 13. p. 11-125

FREUD, Sigmund (1990b). O futuro de uma ilusão, o mal-estar da civilização e outros trabalhos (19271931). In: FREUD, Sigmund. Edição standard das obras psicológicas completas de Sigmund Freud. Rio de Janeiro: Imago. v. 21.

GOMES, Carlos Magno Santos (2013a). As faces da escritora no romance de Lygia Fagundes Telles. Mesa redonda. In: COLÓQUIO MULHERES EM LETRAS, 5., 18 a 20 abr., Universidade Federal de Minas Gerais, Belo Horizonte.

GOMES, Carlos Magno Santos (2013b). Leituras da violência nos contos de Lygia Fagundes Telles. In: COLÓQUIO MULHERES EM LETRAS, 5., 18 a 20 abr., Universidade Federal de Minas Gerais, Belo Horizonte.

KAFKA, Franz (1991). A metamorfose. Tradução de Modesto Carone. São Paulo: Editora Brasiliense.

LUCENA, Suênio Campos de (2013). Representações da memória e da família em Lygia Fagundes Telles. Mesa redonda. In: COLÓQUIO MULHERES EM LETRAS, 5., 18 a 20 abr., Universidade Federal de Minas Gerais, Belo Horizonte.

MACIEL, Maria Esther (Org.) (2011). Pensar / escrever o animal: ensaios de zoopoética e biopolítica. Florianópolis: Editora da UFSC.

SANTIAGO, Silviano (2009). O avesso da festa. In: TELLES, Lygia Fagundes. Ciranda de pedra. São Paulo: Companhia das Letras.

SINGER, Peter (2008). Libertação animal. Porto: Via Óptima.

TELLES, Lygia Fagundes (1989). As horas nuas. Rio de Janeiro: Nova Fronteira.

TELLES, Lygia Fagundes (2009). Ciranda de pedra. São Paulo: Companhia das Letras. 